NOTE

\title{
Anguillicola crassus in the Baltic Sea: field data supporting transmission in brackish waters
}

\author{
L. W. Reimer ${ }^{1}$, A. Hildebrand ${ }^{2}$, D. Scharberth ${ }^{2}$, U. Walter ${ }^{3}$ \\ ${ }^{1}$ Institut für Ostseeforschung, Seestr. 15, D-18119 Warnemünde, Germany \\ ${ }^{2}$ Fachbereich Biologie der Universität Rostock, Wismarsche Str. 8, D-18055 Rostock, Germany \\ ${ }^{3}$ Meeresbiologische Station der Universität Rostock, D-23974 Boiensdorf, Germany
}

ABSTRACT: Between 1990 and 1992 deep-snouted pipefish Syngnathus typhle and black goby Gobius niger were found to be infested by Stage 3 and 4 larvae and preadults of the swim bladder nematode Anguillicola crassus in Wismar Bay (southwestern Baltic Sea) at a frequency of 9.6 and $0.7 \%$, respectively. The high prevalence $(59.4 \%)$ of nematodes in European eels Anguilla anguilla in the Baltic may therefore be attributable not only to freshwater habitation of some eels, but also to the possibility that they feed on affected copepods and small fishes in the brackish waters of the Baltic Sea.

KEY WORDS: Anguillicola crassus $\cdot$ Nematoda $\cdot$ Syngnathus typhle Transmission in brackish water $\cdot$ Baltic Sea

In the past several decades, a number of parasitic species have been introduced into Europe. For example, in the 1960s and 1970s protozoans, cestodes and other kinds of parasites were imported with east Asian carps (Schäperclaus 1979).

In European eels Anguilla anguilla (L.), parasites which have been newly introduced to date include the genera Pseudodactylogyrus Gussev, 1965, Anguillicola Yamaguti, 1935, and Paratenuisentis Bullock \& Samuel, 1975 (Molnár 1984, Peters \& Hartmann 1986, Taraschewski et al. 1987). One such parasite is the swim bladder nematode Anguillicola crassus Kuwahara, Niini \& Itagaki, 1974.

Since the beginning of the 1980s Anguillicola crassus has spread over wide areas of Europe (Køie 1991). Regarding its life cycle in Europe, De Charleroy et al. (1987) and Petter et al. (1990) have listed several entomostracan species known to serve as first intermediate hosts, i.e. the copepods Macrocyclops albidus, $M$. fuscus, Paracyclops fimbriatus, Eucyclops serrulatus, E. macruorides, Cyclops strenuus, $C$. vicinus, Acanthocyclops robustus, $A$. vernalis and Diacyclops bicuspidatus, and the ostracod Cypria ophthalmica. Kennedy \& Fitch (1990) added the copepod Diaptomus gracilis and, from the Malaco- straca, juvenile specimens of the amphipod Gammarus pulex.

Under experimental conditions, Paracyclops fimbriatus has been shown to transmit Stage 3 larvae $\left(\mathrm{L}_{3}\right)$ to eel (De Charleroy et al. 1990), and Acanthocyclops robustus to the guppy Lebistes reticulatus which acts as a second intermediate host (Petter et al. 1989). Kennedy \& Fitch (1990) have also confirmed that larvae are transmitted to eels by Cyclops vicinus and Macrocyclops albidus. Fishes which have been reported as carriers of Anguillicola crassus are listed in Table 1.

Materials and methods. In 1990 and 1991, during an investigation of small littoral fishes in the Salzhaff, part

Table 1. Fishes reported as second intermediate or paratenic hosts for Anguillicola crassus. Fish which accept the $\mathrm{L}_{3}$ from copepods without the larvae molting further are considered paratenic or transport hosts, such as bream and pike perch. If the larvae develop to $\mathrm{L}_{4}$ and preadults, the fish are considered second intermediate hosts

\begin{tabular}{|c|c|c|}
\hline Fish species & $\begin{array}{l}\text { Stages of } \\
\text { A. crassus in fish }\end{array}$ & Source \\
\hline $\begin{array}{l}\text { Abramis brama } \\
\text { (bream) }\end{array}$ & $\mathrm{L}_{3}$ & \multirow{6}{*}{$\begin{array}{l}\text { Haenen } \\
\text { \& Van } \\
\text { Banning } \\
(1990)\end{array}$} \\
\hline $\begin{array}{l}\text { Osmerus eperlanus } \\
\text { (smelt) }\end{array}$ & $\mathrm{L}_{3}, \mathrm{~L}_{4}$ & \\
\hline $\begin{array}{l}\text { Gymnocephalus cernuus } \\
\text { (ruffe) }\end{array}$ & $\mathrm{L}_{3}$, preadults & \\
\hline $\begin{array}{l}\text { Perca fluviatilis } \\
\text { (perch) }\end{array}$ & $\mathrm{L}_{3}$, preadults & \\
\hline $\begin{array}{l}\text { Stizostedion lucioperca } \\
\text { (pike perch) }\end{array}$ & $\mathrm{L}_{3}$ & \\
\hline $\begin{array}{l}\text { Gasterosteus aculeatus } \\
\text { (three-spined stickleback) }\end{array}$ & $\mathrm{L}_{3}, \mathrm{~L}_{4}$, preadults & \\
\hline $\begin{array}{l}\text { Lebistes reticulatus } \\
\text { (guppy) }\end{array}$ & $\mathrm{L}_{3}$ & $\begin{array}{l}\text { Petter } \\
\text { et al. } \\
(1990)\end{array}$ \\
\hline
\end{tabular}




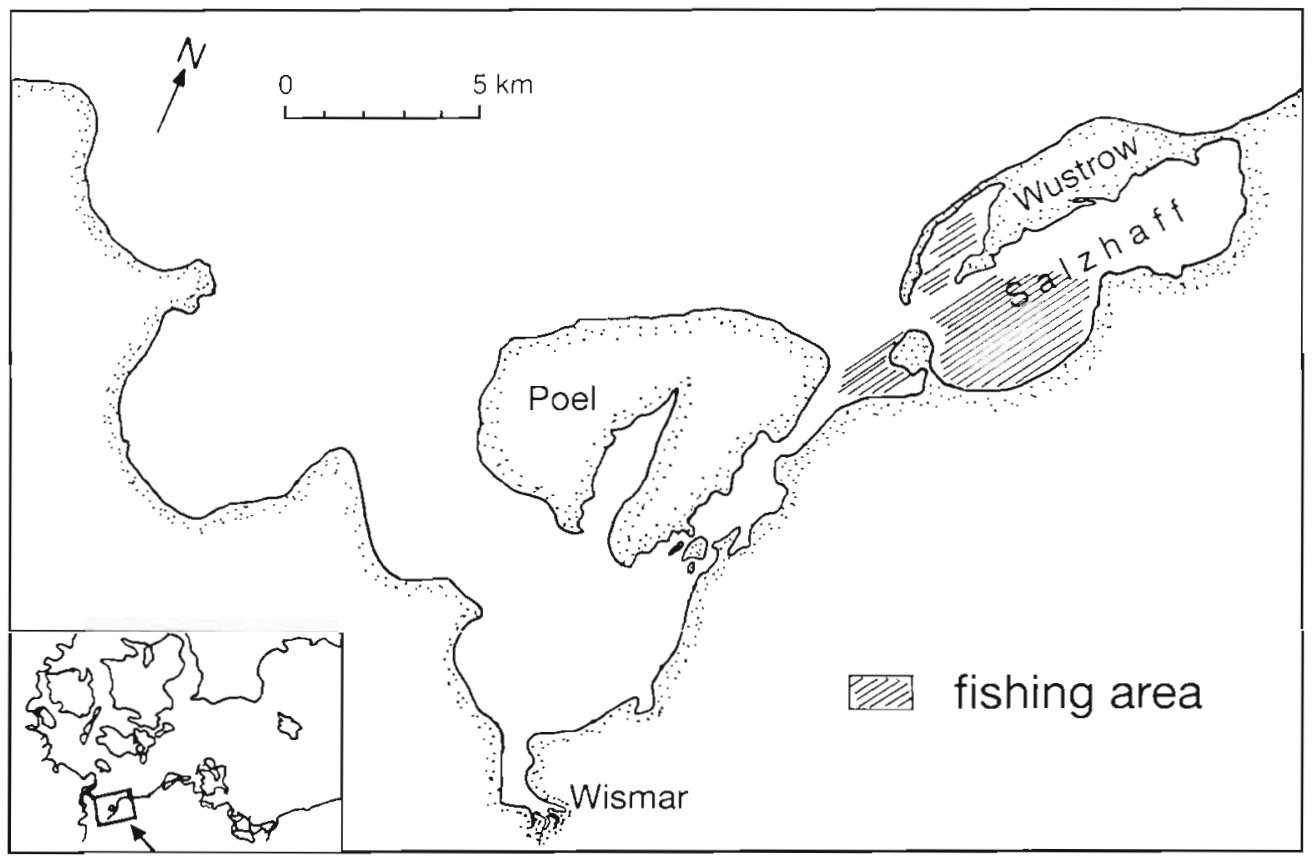

Fig. 1. Wismar Bay, southwestern Baltic Sea. The hatched area indicates where fish were collected for this study of Wismar Bay on the southwestern Baltic Sea (Fig. 1), nematodes and larvae of Anguillicola crassus were sampled.

After observation of live larvae the parasites were fixed and preserved in $75 \%$ ethanol with $5 \%$ glycerol. Smaller specimens were measured in this fluid, while larger ones were first clarified in methyl benzoate. Some of the specimens were mounted in Canada balsam.

Results and discussion. Anguillicola crassus has been observed in eels from the German part of the southern Baltic coast since 1987 (Reimer 1987). In 1990 and subsequent years, during an investigation of small coastal fishes, we found larval specimens of $A$. crassus in the swim bladder of deep-snouted pipefish Syngnathus typhle and black goby Gobius niger.

In Syngnathus typhle ( $\mathrm{n}=178$ ) prevalence was found to be $9.6 \%$. We found parasite stage $\mathrm{L}_{3}$ in the wall and both $\mathrm{L}_{4}$ and preadult stages in the lumen of the swim bladder in this species. The overall length of the investigated pipefish varied between 6.5 and $23 \mathrm{~cm}$ (mean $12.13 \mathrm{~cm}$ ). The infested pipefish ranged from 7.5 to $18.8 \mathrm{~cm}$ in length (mean 13.24), meaning that virtually all size groups of this species were infested. In the western part of the Baltic the deep-snouted pipefish is a part of the eel's diet lown obs. and pers. comm. by fishermen). As part of the food chain this fish is a likely transmitter of the swim bladder nematode.

In Gobius niger $(\mathrm{n}=136)$ parasite prevalence was $0.7 \%$. Only 1 small fish of $5.8 \mathrm{~cm}$ length was infested: we found $1 \mathrm{~L}_{3}$ in the swim bladder wall. The overall length of the fish examined ranged from 4.4 to $10.1 \mathrm{~cm}$ (mean $6.28 \mathrm{~cm}$ )
Recently we also observed $1 \mathrm{~L}_{3}$ larva in the kidney tissue of a flounder $(n=29)$ from Oder Bay, which is surprising, since the swim bladder is lacking in flatfishes. In other fishes that we have investigated, such as other kinds of gobies (Pomatoschistus minutus, $\mathrm{n}=57 ;$ P. microps, $\mathrm{n}=17$; Gobiusculus flavescens, $\mathrm{n}=4$ ), various species of stickleback (Gasterosteus aculeatus, $\mathrm{n}=80$; Pungitius pungitius, $\mathrm{n}=113$; Spinachia spinachia, $\mathrm{n}=46$ ) and pipefish (Nerophis ophidion, $\mathrm{n}=63$ ), we have not found any larval stages of Anguillicola crassus. At present we cannot explain why, in the Baltic, only deep-snouted pipefish and on rare occasions black goby and flounder are affected and not other species, such as the three-spined stickleback, which is invaded in fresh water (Haenen \& Van Banning 1990).

The $\mathrm{L}_{3}$ larvae $(\mathrm{n}=19$ ) of Anguillicola crassus observed in this study were 0.43 to $1.06 \mathrm{~mm}$ long (mean $0.74 \mathrm{~mm}$ ), with an oesophagus of 0.22 to $0.42 \mathrm{~mm}$ (mean $0.32 \mathrm{~mm}$ ). $\mathrm{L}_{4}$ larvae $(\mathrm{n}=7$ ) were 1.05 to $1.69 \mathrm{~mm}$ long (mean $0.45 \mathrm{~mm}$ ). The single preadult specimen had a length of $7.5 \mathrm{~mm}$, with an oesophagus of $0.68 \mathrm{~mm}$ and a buccal capsule of $0.17 \times 0.045 \mathrm{~mm}$. The $\mathrm{L}_{3}$ is equipped with a larval tooth; $\mathrm{L}_{4}$ and preadults possess a buccal capsule with 22 to 28 teeth $(n=8$; mean 26 teeth). The size of the buccal capsule in $\mathrm{L}_{4}$ and preadult stages was $0.17-0.020 \times 0.020-0.045 \mathrm{~mm}$. In adult speciments it is $0.021-0.027 \times 0.048-0.063 \mathrm{~mm}$ (Taraschewski et al. 1987). We identified $\mathrm{L}_{3}$ by comparing their morphological features with those of older stages $L_{4}$ and preadults could be identified with certainty by counting the teeth of the buccal capsule. 
Most authors cited above have mentioned the freshwater character of this nematode parasite. But Kennedy \& Fitch (1990) proved that $\mathrm{L}_{2}$ can survive not only in fresh water, but also in 25,50 and $100 \%$ seawater. In $25 \%$ seawater (ca $8.5 \%$ S), the hatching rate reached $75 \%$, and survival and infectivity were highest. A brackish-water copepod, Eurytemora affinis, that was accidentally introduced in their experiments became infested.

In addition, De Charleroy et al. (1989) have reported the viability of free-living Anguillicola crassus larvae in brackish water of $15 \%$; at this salinity, the larvae lived for more than $3 \mathrm{wk}$. However, during an experiment involving malacostracan crustaceans, Køie (1991) failed to infect Gammarus sp., Corophium volutator, Idothea sp., and Sphaeroma sp. in 15\% salinity.

The average salinity in the Salzhaff (see Fig. 1) is 11 to $12 \%$. In preliminary investigations of eels collected in this area we found an average parasite prevalence of $59.4 \%(n=64)$; in eels $<48 \mathrm{~cm}(\mathrm{n}=28)$ prevalence was $46.44 \%$ and intensity was 1.3 (individuals per eel), in eels 49 to $58 \mathrm{~cm}$ long ( $n=22$ ) prevalence was $54.4 \%$ and intensity was 2.2 , and in eels $>59 \mathrm{~cm}(\mathrm{n}=14)$ prevalence was $92.9 \%$ and intensity was 4.1 .

It can be assumed that large eels become infested in the brackish environment of the Baltic due to the presence of larval stages in paratenic hosts inhabiting these waters. It is possible that the Baltic Sea, with its mesohaline brackish-water conditions, has favoured the spread of Anguillicola crassus.

Acknowledgements. The authors thank the Hansische Gesellschaft e.V., Rostock, for sponsoring this investigation.

\section{LITERATURE CITED}

De Charleroy, D., Grisez, T., Lang, K., Belpaire, C., Ollevier, F (1990). The life cycle of Anguillicola crassus. Dis. aquat Org. 8: $77-84$

De Charleroy, D., Thomas, K., Belpaire, C. (1987). Problems

Responsible Subject Editor: W. Körting, Hannover, Germany concerning the species determination, biology and diagnostical methods of Anguillicola, a swim bladder nematode in the European eel (Anguilla anguilla L.). European Inland Fisheries Advisory Commission (FAO), Working Party on Eel, Bristol, UK, April 13-16, 1987

De (harleroy, D., Thomas K., Belpaire, C., Ollevier, F. (1989) The viability of the free living larvae of Anguillicola crassus. J. appl. Ichthyol. 5: 154-156

Haenen, O. L. M., Van Banning, P. (1990). Detection of larvae of Anguillicola crassus (an eel swim bladder nematode) in fresh water species. Aquaculture 87: 103-109

Hartmann, F. (1991). Neue Untersuchungen über den Aalparasiten Anguillicola crassus. Arb. dt. Fisch.-Verb. 51: $1-12$

Kennedy, C. R., Fitch, D. J. (1990). Colonization, larval survival and epidemiology of the nematode Anguillicola crassus, parasitic in eel, Anguilla anguilla, in Britain. J. Fish Biol. 36: 117-131

Køie, M. (1991). Swim bladder nematodes (Anguillicola spp.) and gill monogeneans (Pseudodactylogyros spp.) parasitic on the European eel (Anguilla anguilla). J. Cons. int. Explor. Mer 47: 391-398

Molnár, K. (1984). Occurrence of new monogeneans of fareast origin on the gills of fishes in Hungary. Acta vet. hung. 32: 153-157

Peters, G., Hartmann, F. (1986). Anguillicola, a parasitic nematode of the swim bladder spreading among eel populations in Europe. Dis. aquat. Org. 1: 229-230

Petter, A. J., Cassone, J., Le Belle, N. (1990). Observations sur la biologie des premiers stades larvaires d'Anguillicola crassus, nematode parasite d'anguille. Ann. Parasitol. hum. comp. 65: 28-31

Petter, A. J., Fontaine, Y A., Le Belle, N. (1989). Etude du développement larvaire d'Anguillicola crassus (Dracunculoidea, Nematoda) chez un Cyclopidae de la région parisienne. Ann. Parasitol. hum. comp. 64: 347-355

Reimer, L. W. (1987). Bewegungen der Aale der Ostsee vor der Laichwanderung auf Grund ihrer Parasitierung. Wiss Z. Pädagogische Hochschule Güstrow, Math.-Nat. Fak 1987(2): $157-166$

Schäperclaus, W. (1979). Fischkrankheiten. AkademieVerlag, Berlin

Taraschewski, H., Moravec, F., Lamah, T., Anders, K. (1987) Distribution and morphology of two helminths recently introduced in European eel populations: Anguillicola crassus (Nematoda, Dracunculoidea) and Paratenuisentis ambiguus (Acanthocephala, Tenuisentidea). Dis. aquat. Org. 3: 167-176

Manuscript first received: November 13, 1992 Revised version accepted: August 30, 1993 